\title{
Transatlantica
}

Revue d'études américaines. American Studies Journal

\section{Tim Groenland, The Art of Editing: Raymond Carver and David Foster Wallace}

\section{Baharak Darougari}

\section{(2) OpenEdition}

\section{Journals}

Electronic version

URL: https://journals.openedition.org/transatlantica/14618

DOI: 10.4000/transatlantica. 14618

ISSN: $1765-2766$

\section{Publisher}

Association française d'Etudes Américaines (AFEA)

\section{Electronic reference}

Baharak Darougari, "Tim Groenland, The Art of Editing: Raymond Carver and David Foster Wallace", Transatlantica [Online], 2 | 2019, Online since 29 October 2020, connection on 02 February 2023. URL: http://journals.openedition.org/transatlantica/14618; DOI: https://doi.org/10.4000/transatlantica. 14618

This text was automatically generated on 2 February 2023.

\section{(†)

Creative Commons - Attribution-NonCommercial-NoDerivatives 4.0 International - CC BY-NC-ND 4.0 https://creativecommons.org/licenses/by-nc-nd/4.0/ 


\title{
Tim Groenland, The Art of Editing: Raymond Carver and David Foster Wallace
}

\author{
Baharak Darougari
}

\section{REFERENCES}

Tim Groenland, The Art of Editing: Raymond Carver and David Foster Wallace, London:

Bloomsbury Academic, 2019. Xvii + 268 pages. ISBN-13: 978-1501338274, $85.60 €$.

1 The editor's integral role in the production of a literary piece has traditionally been overlooked in favor of solitary authorship. Tim Groenland's meticulously researched book seeks to turn the spotlight on the hidden figure behind the author and evaluate the role of the self-effacing editor in the literary process. A thorough examination of archival material has enabled Groenland to study two significant author-editor collaborations of the twentieth century. First, Groenland focuses on the indispensable role of Gordon Lish in the development of Raymond Carver's work from the late 1960s onward, and attempts to appraise the editor's impact on the author's style, legacy, and the rise of minimalism. The second half of the book presents a close study of Michael Pietsch's contribution to David Foster Wallace's most celebrated works, both during Wallace's life and posthumously. The juxtaposition of Carver's minimalist and Wallace's expansive narrative styles makes for an interesting examination of editorial intervention and the exploration of various agents and forces at work in the creation of a literary piece.

2 Groenland addresses the paradoxical assumptions regarding the editor's role in literary culture in the first chapter, and asserts that the editor's status, even in the case of a celebrated editor such as Max Perkins, still remains ambiguous. The editor is expected to be assertive, yet compliant; to assume the position of the co-author and yet minimize his contribution in order to avoid overshadowing the author; to maintain a 
professional distance, and yet be aware of, and pliantly adapt to, different writers' methods, requests and idiosyncrasies in order to forge a working relationship so intimate that it can also be defined as friendship. These contradictory expectations hinder a clear understanding of what the editor's job entails. Groenland shifts the available definitions from the romanticized notion of the editor as the one who envisions "what a text can be" (Greenberg 19) to a practical understanding of the editorial process, which includes activities such as "reviewing, revising, redacting, refining, amending and correcting" (Sharpe 131). However, he observes that the final product rarely reflects the editor's input since authors, the publishing industry, and even editors still favor the paradigm of single authorship to ensure the author's legacy, the commercial success of the book, and in the editors' case, their jobs. Thus, studying the development of the editorial process requires a close reading of various versions of the text and an examination of the author and the editor's relationship in a given social and historical context. Drawing on genetic criticism, Groenland traces the editorial impact of two prominent figures who embody the aforementioned contradictions in the following chapters: Lish, who rightfully sought to be acknowledged for his contribution to Carver's work, and Pietsch, the elusive figure behind the author. Studying the dichotomous approaches of the aforementioned editors allows Groenland to establish a narrative of creation in order to trace the significance of the editor's role in the development of Carver and Wallace's most celebrated works which have shaped the literary landscape of the twentieth century.

3 The Art of Editing revisits Lish's role in the evolution of Carver's work and the construction of his image. The second chapter of the book compares the original and the edited versions of Carver's first collection, Will You Please Be Quiet, Please? in order to establish Lish's aesthetic vision and study his methods. Groenland's extensive analyses of "Neighbors," "Will You Please Be Quiet, Please?", “A Dog Story," and "A Student's Wife" indicate considerable alteration of the narrative method and the story length. Groenland observes that Lish deliberately withholds information from the readers, removes adjectives, minimizes verbal communication, and disposes of characters' inner thoughts, flashbacks, pastoral scenes, and anything that may suggest sentimentality. The final version is far less explicit than Carver's, and yet the selective omission adds tension. The curtailed dialogue accentuates the loneliness of the characters. The abrupt transitions and opaque-ending sentences leave the conclusion(s) to the reader's imagination. Groenland's reading of the stories indicates that Lish is responsible to a great extent for the precision and compression which exemplify Carver's style and, consequently, the minimalist movement.

4 Groenland's scrupulous reading of What We Talk About When We Talk About Love (a comparison of "A Small Good Thing" and "The Bath," and an examination of various versions of "Friendship" and "If You Please") in the third chapter shows the expansion and the evolution of the methods identified in the previous chapter in the creation of "the quintessential Carver text" and "the ur-text of minimalism" (61). The comparative reading of the texts demonstrates the removal and/or replacement of paragraphs as well as significant changes in tone, lexicon, syntax, and narrative. Groenland demonstrates how Lish repurposes the elements of the stories in order to create "thematic and acoustical consecution" (82) and establish intertextual links which result in a formal unity among the stories. Lish's audacious modifications to Beginners (the original title of What We Talk About When We Talk About Love), including the title, resulted in the celebration of the book as the touchstone of 1980s fiction, and 
established the author as the accomplished chronicler of the inarticulate, vulnerable working class.

Groenland is equally interested in the Lish-Carver collaboration on a personal level. His close reading of the editor and author's correspondence indicates Carver's conflicted attitude toward his editor and What We Talk About When We Talk About Love, the book which created his legacy. In his letters to Lish, he lamented over the loss of warmth and human moments in his heavily edited stories, and yet claimed frequent revisions and rewritings as his own process in the interviews. Carver's departure from Lish's economic style in Cathedral and the inclusion of the unedited version of his stories in the subsequent collections marked the end of a productive collaboration and the departure of fiction from the aesthetics of minimalism towards a more expressive approach exemplified in Wallace's Infinite Jest.

Michael Pietsch and David Foster Wallace's collaboration on Infinite Jest highlights the intervenient role of the editor as the mediator between the author and the reader, or the author and the publisher. Groenland argues that the editor's approach to an excessive text and a pugnacious author ensured the commercial and critical success of the book. As a master grammarian and an opinionated author who had adopted the editor's role from time to time, Wallace resisted reductions vehemently. Moreover, the scope of the text made intervention on the sentence level an increasingly onerous task. Groenland demonstrates how Pietsch's diplomatic negotiations with Wallace resulted in the compression and rearrangement of the material in favor of narrative cohesion and plot development with the aim of creating a pleasurable reading experience. Pietsch also used the distinctive feature of the text, namely its verbosity, as an effective marketing strategy which guaranteed the book's commercial success and affected its critical reception. Using the gargantuan size of the book as evidence of an accomplished author's brilliance, Pietsch's marketing campaign confronted the critics and the general readers with a simple question: "Are you reader enough?" (134). This tempting challenge ensnared the critics and the public alike, established Wallace as an ambitious and intellectual author, and secured the editor's reputation.

7 The posthumous compilation of The Pale King provides Groenland with the opportunity to study the editorial function without authorial guidance. Groenland acknowledges Pietsch's remarkable accomplishment in the compilation of Wallace's novel from the colossal drafts, notes, and research archives he had left behind. He admires Pietsch's decision to edit toward thematic consistency, and provide the readers with footnotes and archive indices to illustrate Wallace's process. However, he makes a compelling case for the indispensability of some of the excised material to the central themes of the novel through his minute study of "Cede," and points out that the text is the product of a constructive yet tense collaboration between the author and the editor. The deletion of each factor from the equation will undoubtedly affect the coherence and, therefore, stability of the text.

In the last chapter, Groenland traces the impact of the editorial collaborations Carver and Wallace experienced in their subsequent works. He argues that the discomfort, the unease, and the loss of control felt during the editorial transaction have a lasting impact on the author who internalizes the tension and struggles, and develops a heightened awareness of the editing process and the social context. This condition, which Groenland calls "the anxiety of editorial influence" (206), makes the author adopt an editor and/or reader persona in regard to his writing and may result in 
intentional or unconscious self-editing during the compositional process. The anxiety of editorial influence may also manifest thematically in the author's work. Groenland argues that Carver allegorically recorded his turbulent relationship with Lish and the loss of control he had experienced in his later work, especially "Cathedral." The metafictional tendencies of The Pale King along with Wallace's self-addressed notes indicate his constant questioning and self-awareness. In both cases, the struggles and difficulties of the editing process left a mark and became a driving force behind the writers' quest of perfection.

The Art of Editing examines two enduring partnerships in order to study the editor's multifaceted role in the process of writing. However, Groenland's close reading of the outstanding outcomes of the author-editor relationship surpasses a simple definition or a job description. A thorough examination of an authoritative editor's impact on minimalist fiction side by side with an elusive editor's contributions to maximalist fiction allows Groenland to display the dynamics at work in social, historical, and personal context. He argues that writing, contrary to popular belief, is not a solitary act, and the evaluation of the history of its making can nourish and nuance its possible interpretations. Exceptional literary pieces are the products of complicated, yet fruitful author-editor relationships. It is time for the editor to step out of the shadows and take his rightful place beside the author.

\section{BIBLIOGRAPHY}

GREENBERG, Susan. "When the Editor Disappears, Does Editing Disappear?" Convergence: The International Journal of Research into New Media Technologies, vol. 16, no. 1, 2010, p. 7-21.

SHARPE, Leslie T., and Irene GUNTHER. Editing Fact and Fiction: A Concise Guide to Book Editing. Cambridge: Cambridge University Press, 1994.

\section{INDEX}

Subjects: Recensions

\section{AUTHORS}

\section{BAHARAK DAROUGARI}

Université de Strasbourg/UR SEARCH 2325 